\title{
ENDORPHINS AND THE HYPOTENSIVE RESPONSE TO STIMULATION OF ALPHA-RECEPTORS IN THE BRAINSTEM BY ALPHA-METHYLNORADRENALINE
}

\author{
Margaret A. Petty and W. De Jong \\ Rudolf Magnus Institute for Pharmacology, Medical Faculty, University of Utrecht, Vondellaan 6, 3521 \\ GD Utrecht, The Netherlands
}

(Accepted 1 November 1983)

\begin{abstract}
Summary-Opioid peptide involvement in the fall in blood pressure resulting from stimulation of alpha-receptors in the brainstem has been investigated in the urethane-anaesthetised rat. Unilateral microinjection of alpha-methylnoradrenaline into the nucleus tractus solitarii (NTS) induced a doserelated fall in blood pressure and heart rate. The depressor response induced by the amine was prevented by pretreatment with naloxone, administered either subcutaneously or directly into the nucleus. Pretreatment with antiserum to beta-endorphin, applied locally, also blocked the depressor response, however a similar dilution of antiserum to met-enkephalin was ineffective in this respect. The local application of phentolamine into the $\mathrm{n}$. tractus solitarii caused an initial fall in both blood pressure and heart rate, and blocked the cardiovascular changes induced by alpha-methylnoradrenaline for at least $90 \mathrm{~min}$. Pretreatment with the alpha-receptor antagonist attenuated the fall in blood pressure produced by microinjection of beta-endorphin. These results suggest that the fall in blood pressure observed after administration of alpha-methylnoradrenaline involves a beta-endorphin-like peptide, a probable site of this interaction being the $\mathrm{n}$. tractus solitarii.
\end{abstract}

Key words: nucleus tractus solitarii, alpha-methylnoradrenaline, blood pressure, opioid peptides, antiserum to beta endorphin, naloxone.

Clonidine, analogous to morphine and endogenous opioids, has been reported to induce analgesia (Paalzow and Paalzow, 1976) and its withdrawal elicits symptoms similar to those of opiate withdrawal (Reid, Dargie, Davies, Wing, Hamilton and Dollery, 1977). Furthermore, clonidine inhibits the clinical symptoms of opiate withdrawal in addicts (Gold, Redmond and Kleber, 1978) and the associated increase in metabolites of noradrenaline in brain (Crawley, Laverty and Roth, 1979). Morphine suppresses the blood pressure response to withdrawal of clonidine in spontaneously hypertensive rats (SHR) (Thoolen, Timmermans and Van Zwieten, 1981). These similarities suggest some interaction between central opioid and alpha-adrenoceptor systems. In fact, Pettibone and Meuller (1981a, b) have reported that an alpha-adrenergic mechanism influences the release of pituitary beta-endorphin in the rat, particularly from the anterior lobe.

In conscious rats, the decrease in blood pressure and heart rate induced by i.v. injection of clonidine and alpha-methyldopa is reversed by naloxone (Farsang and Kunos, 1979), indicating that alphaadrenoceptor stimulation involves the activation of opiate receptors. Since naloxone and clonidine appear not to interact with the same receptor site, it was suggested that clonidine and alpha-methyldopa induce the release of an endogenous opioid peptide, which is involved in the central control of sympathetic tone (Farsang, Ramirez-Gonzalez, Mucci and Kunos, 1980). More recently it has been reported that clonidine and alpha-methylnoradrenaline, a probable active metabolite of alpha-methyldopa, induce the release of a peptide with beta-endorphin-like immunoreactivity from brainstem slices of spontaneously hypertensive rats, but not from their normotensive, genetically matched. Wistar Kyoto controls (Kunos, Farsang and Ramirez-Gonzalez, 1981). This response is specific for the active L-isomer of alpha-methylnoradrenaline and is reduced by yohimbine. On the basis of these findings, Kunos et al. (1981) speculated that the release of beta-endorphinlike material in the brainstem contributes to the antihypertensive action of central alpha-adrenoceptor stimulants in the hypertensive rat.

Beta-endorphin-containing perikarya appear to be predominantly located in the medial basal hypothalamus, with axons widely distributed throughout the brain (Watson, Akil, Berger and Barchas, 1979). Both beta-endorphin nerve fibres and terminals have been demonstrated in the nucleus tractus solitarii (NTS) in the brainstem (Finley, Lindström and Petrusz, 1981; Palkovits, '1981), which is the first synapse in the baroreceptor reflex arc. Betaendorphin binding sites have been located in many brainstem areas (Law, Loh and Li, 1979; Akil, Hewlett, Barchas and $\mathrm{Li}, 1980$ ). Unilateral microinjection of the peptide into the nucleus tractus solitarii of the urethane-anaesthetised rat results in a dose-related fall in blood pressure and heart rate (Petty, De Jong and De Wied, 1982; Petty and De Jong, 1982). The hypotensive effects, which are naloxone reversible are 
anatomically specific and restricted to the intermediate third of the $n$. tractus solitarii. The local application of antiserum to beta-endorphin causes a rise in both blood pressure and heart rate.

There is a dense catecholaminergic innervation of the $n$. tractus solitarii and the noradrenalinecontaining perikarya ( $A_{2}$ region) are located close to the region of the baroreceptor terminals (Palkovits and Záborsky, 1977; Palkovits, Mezey and Záborsky, 1979; Palkovits, 1980), where they appear to modulate the tonic inhibitory control and reflex regulation of cardiovascular function. Microinjection studies have revealed that the medio-caudal area, corresponding to the $A_{2}$ region, of the $n$. tractus solitarii is the most sensitive to applied catecholamines (Zandberg and De Jong, 1977), where they induce a decrease in blood pressure and heart rate. The $n$. tractus solitarii also appears to be a site of action of the centrally acting hypotensive agents, including clonidine and alpha-methyldopa (Haeusler, 1973; De Jong, 1974; Nijkamp and De Jong, 1975; Rockhold and Caldwell, 1980; Schmitt, Schmitt and Fćnard, 1971; Zandberg, De Jong and De Wied, 1979). The medio-caudal part of the $n$. tractus solitarii appears therefore to mediate some cardiovascular changes induced by both beta-endorphin and the catecholamines, and for this reason a possible interaction at the level of this nucleus has been examined.

\section{METHODS}

Experiments were carried out in urethaneanaesthetised $(1.4 \mathrm{~g} / \mathrm{kg})$, normotensive, male Wistar rats (CPB-TNO, Zeist, The Netherlands), weighing $200-250 \mathrm{~g}$. A carotid artery was catheterised for direct measurement of mean arterial pressure (MAP), which was recorded by means of a Statham P23-AC gauge transducer and displayed on a Grass polygraph. Heart rate (HR) was calculated from the arterial pressure recording.

The rat was placed in a stereotaxic head holder, and the head fixed to an angle of $45^{\circ}$ downward. A limited occipital craniotomy was carried out to expose the dorsal surface of the lower brainstem. The caudal tip of the area postrema in the midline was used as a rostro-caudal zero, corresponding to $p$ $7.4 \mathrm{~mm}$ of the atlas of Palkovits and Jacobowitz
(1974). Microinjections into the $n$. tractus solitarii were made on the right side of the medulla oblongata $(0.5 \mathrm{~mm}$ lateral of the midline and $0.9 \mathrm{~mm}$ below the dorsal surface of the medulla oblongata), by means of a glass cannula (outer diameter $60 \mu \mathrm{m}$ ) in a volume of $0.4 \mu 1$ which was delivered in $10 \mathrm{sec}$ (Zandberg $e t$ al., 1979). Control rats received an equivalent volume of vehicle. After the experiment the correct position of the injection site was confirmed by histology.

\section{Drugs and chemicals}

The following drugs were used: \pm alphamethylnoradrenaline- $\mathrm{HCl}$ (Cobefrin, Sterling-Winthrop Research Institute, Rensselaer, New York, U.S.A.); naloxone- $\mathrm{HCl}$ (Endo Laboratories, New York, U.S.A.); beta-endorphin (beta-LPH 61-91) (Organon International B.V., Oss, The Netherlands); antiserum to beta-endorphin and antiserum to metenkephalin (kindly given by Dr V. M. Wiegant); control rabbit serum; phentolamine (Regitine, Ciba-Geigy B. V., Arnhem, The Netherlands). All agents were dissolved in or diluted with $0.9 \% \mathrm{NaCl}$ (saline).

\section{Statistics}

All values used in the analysis represent the mean \pm SD of $6-8$ determinations. The significance of differences between test animals and their controls were calculated by means of a Student's $t$-test for unpaired data, or where appropriate an Analysis of Variance with application of the Neuman-Keuls test.

\section{RESULTS}

Unilateral administration of alpha-methylnoradrenaline into the $\mathrm{n}$. tractus solitarii caused a dose-dependent decrease in blood pressure and heart rate (Table 1). The fall in arterial pressure was apparent with a dose of $1.1 \mu \mathrm{g}$, although it was not accompanicd by a decrease in heart rate. With larger doses $(11$ and $33 \mu \mathrm{g})$ the decrease in arterial pressure was more pronounced and prolonged, however it did not become evident until 2-5 min after administration. The fall in arterial pressure which occurred with these larger doses was always accompanied by bradycardia.

Table 1. The change in mean arterial pressure (MAP) and heart rate (HR) induced by various doses of ( \pm ) alpha-methylnoradrenaline after administration into the nucleus tractus solitarii of the urethane-anaesthetised rat

\begin{tabular}{|c|c|c|c|c|c|c|c|}
\hline \multirow[b]{2}{*}{ Doses } & \multirow{2}{*}{$\begin{array}{c}\text { Basal blood } \\
\text { pressure (mmHg) } \\
\text { and heart rate }(\mathrm{bpm})\end{array}$} & \multicolumn{6}{|c|}{$\triangle M A P$ and $H R$} \\
\hline & & 2 & 5 & 10 & 15 & 30 & $60 \mathrm{~min}$ \\
\hline 1) 1 & $\begin{array}{l}124 \pm 12 \\
424 \pm 33\end{array}$ & $\begin{array}{l}-1 \pm 1 \\
-4 \pm 3\end{array}$ & $\begin{array}{c}-1 \pm 3 \\
-11 \pm 10\end{array}$ & $\begin{array}{r}0 \pm 2 \\
-10 \pm 9\end{array}$ & $\begin{array}{r}2 \pm 2 \\
-9 \pm 7\end{array}$ & $\begin{array}{l}6 \pm 6 \\
2 \pm 8\end{array}$ & $\begin{array}{c}2 \pm 7 \\
4 \pm 13\end{array}$ \\
\hline \pm Alpha-methylnoradrenaline & & & & & & & \\
\hline $1.1 \mu \mathrm{g}$ & $\begin{array}{l}113 \pm 6 \\
428 \pm 17\end{array}$ & $\begin{array}{l}-9 \pm 6 \\
-5 \pm 4\end{array}$ & $\begin{array}{l}-15 \pm 6 \\
-11 \pm 10\end{array}$ & $\begin{array}{r}-17 \pm 4 \\
-8 \pm 6\end{array}$ & $\begin{array}{r}-13 \pm 5 \\
-8 \pm 6\end{array}$ & $\begin{array}{l}-5 \pm 5 \\
-7 \pm 11\end{array}$ & $\begin{array}{r}2 \pm 5 \\
-3 \pm 9\end{array}$ \\
\hline $11 \mu \mathrm{g}$ & $\begin{array}{l}123 \pm 7 \\
430 \pm 30\end{array}$ & $\begin{array}{r}2 \pm 16 \\
-9 \pm 15\end{array}$ & $\begin{array}{l}-17 \pm 12 \\
-27 \pm 22\end{array}$ & $\begin{array}{l}-25 \pm 9 \\
-30 \pm 18\end{array}$ & $\begin{array}{l}-20 \pm 9 \\
-38 \pm 17\end{array}$ & $\begin{array}{c}-7 \pm 5 \\
-39 \pm 17\end{array}$ & $\begin{array}{c}-3 \pm 4 \\
-22 \pm 19\end{array}$ \\
\hline $33 \mu \mathrm{g}$ & $\begin{array}{l}125 \pm 11 \\
423 \pm 24\end{array}$ & $\begin{array}{r}12 \pm 11 \\
7 \pm 18 \\
\end{array}$ & $\begin{array}{r}-3 \pm 16 \\
-17 \pm 21\end{array}$ & $\begin{array}{l}-28 \pm 12 \\
-55 \pm 26 \\
\end{array}$ & $\begin{array}{l}-35 \pm 12 \\
-64 \pm 18 \\
\end{array}$ & $\begin{array}{l}-25 \pm 7 \\
-63 \pm 22 \\
\end{array}$ & $\begin{array}{l}-15 \pm 4 \\
-47 \pm 19 \\
\end{array}$ \\
\hline
\end{tabular}

Results are expressed as the mean $\pm \mathrm{SD}, n=6$. 


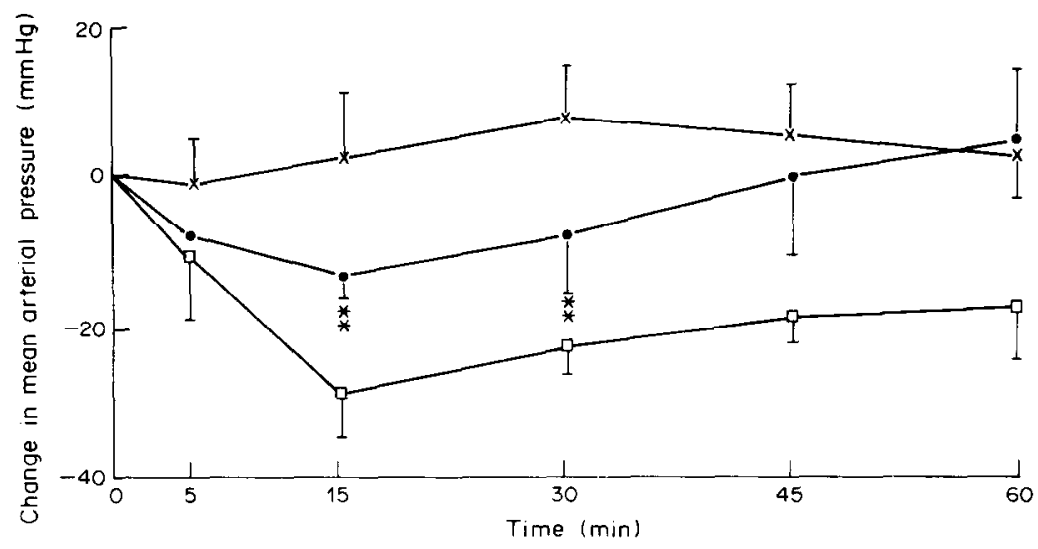

Fig. 1. The effect of pretreatment with naloxone $(1 \mathrm{and} 10 \mathrm{ng})(10 \mathrm{~min})$ into the nucleus tractus solitarii on the fall in mean arterial pressure induced by the microinjection of \pm alpha-methylnoradrenaline $(11 \mu \mathrm{g})$ in the urethane-anaesthetised rat. $(\square-\square)$ Saline and alpha-methylnoradrenaline; ( $\longrightarrow-1 \mathrm{ng}$ naloxone and alpha-methylnoradrenaline; $(x-x) 10 \mathrm{ng}$ naloxone and alpha-methylnoradrenaline. Results are expressed as the mean \pm SD of 6 animals in each group and were compared by an analysis of variance with application of the Neuman Keuls test. From 15 min onward, the mean arterial pressure of each group was significantly different $\left({ }^{* *} P<0.01\right)$ from the other two groups. However, at 45 min when the arterial pressure of the groups given $1 \mathrm{ng}$ naloxone and alpha-methylnoradrenaline, $10 \mathrm{ng}$ naloxone and alpha-methylnoradrenaline and control groups were not significantly different, the arterial pressure of the groups given saline and alpha-methylnoradrenaline was, in this instance, still reduced $(P<0.01)$.

\section{Effect of the opiate receptor antagonist naloxone}

Naloxone (1 mg/kg, s.c.), administered $15 \mathrm{~min}$ before an injection of saline into the $n$. tractus solitarii, caused a rise in arterial pressure, which reached a maximum of $8 \pm 4 \mathrm{mmHg} 50-60 \mathrm{~min}$ after the injection $(P<0.001$ when compared to $-2 \pm 2 \mathrm{mmHg}$ in saline-treated controls). When administered $15 \mathrm{~min}$ prior to alpha-methylnoradrenaline $(11 \mu \mathrm{g})$ into the n. tractus solitarii, naloxone $(1 \mathrm{mg} / \mathrm{kg}$, s.c.) blocked the fall in blood pressure and reduced the bradycardia induced by the catecholamine. At the time of the maximum change in both arterial pressure and heart rate these values were $2 \pm 5$ and $-22 \pm 3 \mathrm{mmHg} \quad(P<0.001)$ and $-18 \pm 16$ and $-38 \pm 12 \mathrm{bpm}$ after pretreatment with naloxone and saline, respectively. The local application of naloxone ( 1 and $10 \mathrm{ng}$ ) into the $\mathrm{n}$. tractus solitarii did not affect arterial pressure or heart rate, but $1 \mathrm{ng}$ administered $10 \mathrm{~min}$ prior to alpha-methylnoradrenaline $(11 \mu \mathrm{g})$, partially antagonised the fall in arterial pressure, although it had no effect on the bradycardia induced by the amine. However, a larger dose of the opiate receptor antagonist (10 ng) completely blocked both the fall in arterial pressure (Fig. 1) and heart rate, resulting in the values for arterial pressure and heart rate not being significantly different from those of naloxone- and saline-treated controls.

\section{Effect of the alpha-adrenoceptor antagonist phen- tolamine}

The local application of phentolamine $(1.4 \mu \mathrm{g})$ caused a rapid fall in both arterial pressure and heart rate which reached a maximum of $-15 \pm 5 \mathrm{mmHg}$ and $-76 \pm 23 \mathrm{bpm} 15 \mathrm{~min}$ after administration. Although these cardiovascular changes gradually re- turned to control values, the alpha-adrenoceptor blocking properties of phentolamine were effective for at least $90 \mathrm{~min}$ after injection. This was evident from its ability to completely block the fall in arterial pressure and heart rate induced by alphamethylnoradrenaline $(11 \mu \mathrm{g})$ during this period, for example, when administered $60 \mathrm{~min}$ before the amine, the maximum changes in arterial pressure and heart rate were $-2 \pm 2 \mathrm{mmHg}$ and $6 \pm 2 \mathrm{bpm}$ as compared to $-30 \pm 4 \mathrm{mmHg}$ and $-45 \pm 15 \mathrm{bpm}$ after pretreatment with saline $(P<0.001)$. Phentolamine $(1.4 \mu \mathrm{g})$ administered $20 \mathrm{~min}$ before beta-endorphin ( $1 \mathrm{ng}$ ) into the $\mathrm{n}$. tractus solitarius, significantly antagonised the prolonged fall in arterial pressure induced by the peptide (Fig. 2). At all times tested, the arterial pressure of the group of animals treated with saline and beta-endorphin was significantly lower than that of the group treated with phentolamine and beta-endorphin, the group treated with phentolamine and saline (data not shown) and the saline-treated controls (Fig. 2). There was no significant difference between the values for arterial pressure of the latter three groups of animals.

\section{Effect of pretreatment with antiserum}

In Table 2 the effect of pretreatment $(10 \mathrm{~min})$ with $0.4 \mu \mathrm{l}$ of a 1:50 dilution of antiserum to betaendorphin on the decrease in blood pressure induced by alpha-methylnoradrenaline, as compared to the same dilution of normal rabbit serum, can be seen. Beta-endorphin antiserum blocked the fall in arterial pressure induced by the amine, however although the bradycardia was reduced, this did not achieve statistical significance. It has already been reported that this particular antiserum blocks the fall in blood 


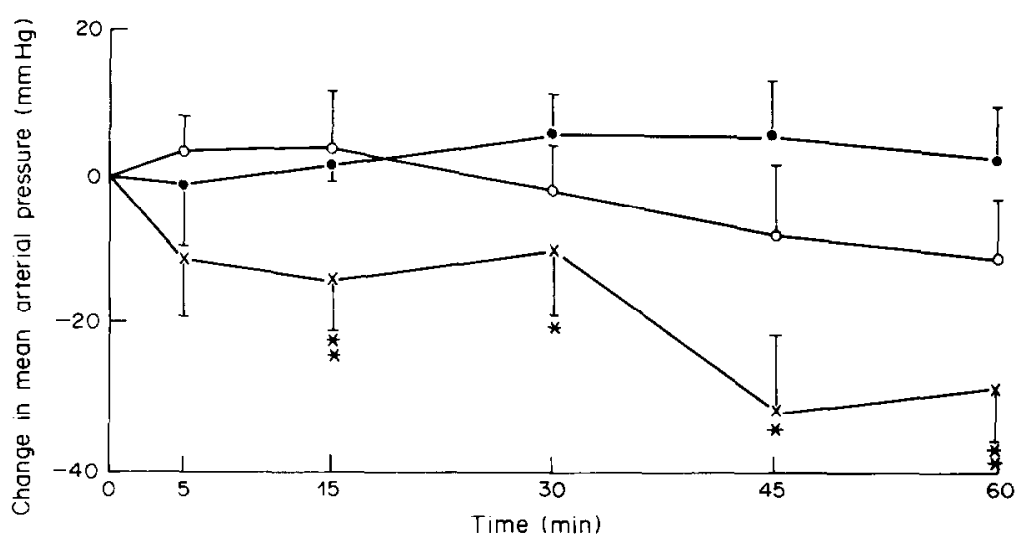

Fig. 2. The effect of pretreatment with phentolamine $(1.4 \mu \mathrm{g})(20 \mathrm{~min})$ on the fall in blood pressure induced by the local application of beta-endorphin $(1 \mathrm{ng})$ into the nucleus tractus solitarii of the urethaneanaesthetised rat. ( - S Saline control; $(0-0)$ phentolamine and beta-endorphin; $(x-x)$ saline and beta-endorphin. Results are expressed as the mean \pm SD of 6 animals in each group. The data were compared by an analysis of variance with application of the Neuman-Keuls test, ${ }^{*} P<0.05$, ${ }^{* *} P<0.01$.

pressure and heart rate resulting from the microinjection of beta-endorphin into the $n$. tractus solitarii, and causes a delayed rise in pressure when administered alone (Petty and De Jong, 1982).

The local application of $0.4 \mu 1$ of a 1:50 dilution of antiserum to met-enkephalin $20 \mathrm{~min}$ prior to the administration of alpha-methylnoradrenaline $(11 \mu \mathrm{g})$ did not affect the blood pressure lowering properties of the amine, which had a tendency to be prolonged, returning to control values after $30 \mathrm{~min}$ (Table 2). The antiserum did not affect the bradycardia induced by alpha-methylnoradrenaline. In a previous publication it has been reported that the local application of this antiserum, which blocked the cardiovascular changes induced by the local injection of D-Ala ${ }^{2}$ Met $^{5}$-enkephalin, caused a rapid fall in arterial pressure which reached a maximum at $10 \mathrm{~min}$, when administered alone (Petty and De Jong, 1982). Therefore, in this study, alpha-methylnoradrenaline was administered $20 \mathrm{~min}$ after the antiserum to prevent interference arising from this depressor response.

\section{DISCUSSION}

In this study the possible involvement of an opioid peptide in the hypotension resulting from activation of central alpha-receptors has been investigated. It has been indicated that the antihypertensive action of clonidine and alpha-methyldopa in unanaesthetised hypertensive rats, is mediated by a beta-endorphinlike peptide, which is released by these centrally acting alpha-agonists (Farsang et al., 1980; Kunos et al., 1981). Since the $\mathrm{n}$. tractus solitarii, containing the first synapse in the baroreflex arc, appears to be a site of action of biogenic amines (De Jong, 1974; Zandbcrg et al., 1979) and beta- and alpha-endorphin (Petty and De Jong, 1982; De Jong, Petty and Sitsen, 1982) in mediating their hypotensive effects, this particular area was investigated as a possible site of such an interaction. Microinjection of alphamethylnoradrenaline into the $\mathrm{n}$. tractus solitarii produced a dose-dependent fall in blood pressure, which was accompanied by bradycardia. Similarly it has been reported that administration of beta-endorphin into the $n$. tractus solitarii induces a dose-related fall in blood pressure and heart rate. The depressor responses in both cases are anatomically specific and restricted to the intermediate third of the $n$. tractus solitarii (Petty and De Jong, 1982; Zandberg and De Jong, 1977). This area corresponds to the A2 region at the level of the caudal part of the area postrema and is densely innervated by catecholaminergic nerve terminals and contains catecholaminergic cell bodies (Palkovits and Záborsky, 1977).

Analogous to the naloxone-reversible depressor response and fall in heart rate induced by betaendorphin, the decrease in both arterial pressure and heart rate produced by alpha-methylnoradrenaline

Table 2. The change in mean arterial pressure (MAP) resulting from the administration of \pm alpha-methylnoradrenaline $(11 \mu \mathrm{g})$ into the nucleus tractus solitarii after pretreatment with a 1:50 dilution of rabbit serum, or antiserum to beta-endorphin or antiserum to met-enkephalin

\begin{tabular}{|c|c|c|c|c|c|c|}
\hline \multirow[b]{2}{*}{ Pretreatment } & \multicolumn{5}{|c|}{$\triangle \mathrm{MAP}$} & \multirow[b]{2}{*}{$60 \mathrm{~min}$} \\
\hline & 2 & 5 & 10 & 15 & 30 & \\
\hline $\begin{array}{l}\text { Rabbit serum } \\
\text { Beta-endorphin antiserum } \\
\text { Rabbit serum } \\
\text { Met-enkephalin antiserum }\end{array}$ & $\begin{array}{r}-10 \pm 11 \\
1 \pm 7^{*} \\
-1 \pm 14 \\
10 \pm 13\end{array}$ & $\begin{aligned}-19 & \pm 5 \\
0 & \pm 9 \ddagger \\
-13 & \pm 9 \\
-6 & \pm 11\end{aligned}$ & $\begin{array}{l}-26 \pm 5 \\
-4 \pm 11+ \\
-20 \pm 6 \\
-17 \pm 17\end{array}$ & $\begin{array}{l}-24 \pm 6 \\
-6 \pm 14 \dagger \\
-15 \pm 6 \\
-19 \pm 16\end{array}$ & $\begin{array}{r}-14 \pm 14 \\
-1 \pm 5^{*} \\
-5 \pm 13 \\
-18 \pm 16\end{array}$ & $\begin{array}{r}2 \pm 8 \\
-2 \pm 6 \\
1 \pm 9 \\
-8.3 \pm 9\end{array}$ \\
\hline
\end{tabular}

Results are expressed as the mean $\pm \mathrm{SD}, n=6$. The significance of differences between test animals and their appropriate controls was calculated by means of a Student's $t$-test for unpaired data. ${ }^{*} P<0.05 ; \dagger P<0.01 ; \ddagger P<0.001$. 
was attenuated by naloxone, the opiate receptor antagonist being administered subcutaneously or directly into the $\mathrm{n}$. tractus solitarii. These findings suggest that the activation of alpha-receptors in the n. tractus solitarii by alpha-methylnoradrenaline, to induce a fall in arterial pressure, requires the stimulation of opiate receptors. However these opiate receptors do not appear to be an integral part of the baroreflex pathway, but may be involved in a neuromodulator system. This seems likely since administration of naloxone into the $\mathrm{n}$. tractus solitarii did not affect the depressor response induced by L-glutamate, which has been proposed to be a neurotransmitter of baroreceptor afferent nerve fibres in the $n$. tractus solitarii (Talman, Perrone and Reis, 1980). The change in arterial pressure induced by L-glutamate $(1 \mu \mathrm{g})$ being $-19 \pm 4$ and $-17 \pm 9 \mathrm{mmHg}$ after pretreatment with saline and naloxone $(10 \mathrm{ng})$ respectively.

The finding that opiate-receptor blockade with naloxone reversed the effects of alphamethylnoradrenaline in urethane-anaesthetised normotensive rats of the Wistar strain, is at variance with the results of Farsang and Kunos (1979) who could only demonstrate this effect in spontaneously hypertensive rats and not in their genetically-matched Wistar Kyoto normotensive controls. However Bennett, Defeo, Elko and Lal (1982) were able to show that naloxone antagonised clonidine-induced hypotension in normotensive Sprague-Dawley and Long-Evans rats. These authors questioned whether Wistar Kyoto normotensive controls. However Bennett, Defeo, Elko and Lal (1982) were able to show that naloxone antagonised clonidine-induced the study of Farsang and Kunos (1979) differed from the present experiments, since unanaesthetised animals were used and were given alpha-methyldopa intraperitoneally.

The type of alpha-receptor in the $n$. tractus solitarii, which is involved in the hypotensive action of alpha-methylnoradrenaline is still a matter of conjecture (De Jong and Petty, 1982). For this reason the alpha-adrenoceptor antagonist, phentolamine, was used in the present study. Pretreatment with phentolamine blocked both the decrease in arterial pressure and heart rate induced by alphamethylnoradrenaline, confirming the findings of Zandberg et al. (1979). However, pretreatment with phentolamine also antagonised the decrease in arterial pressure induced by the local application of beta-endorphin. The possiblility therefore arises that phentolamine is also blocking the action of a further neuroregulator, which may in turn be released to produce the fall in blood pressure seen after microinjection of beta-endorphin. Of the neurotransmitters which have been shown to cause a depressor response upon local application into the n. tractus solitarii, only adrenaline, noradrenaline and dopamine have been reported to induce a fall in arterial pressure which can be antagonised by phentolamine (Zan- dberg et al., 1979; Kubo and Misu, 1981; Smith, Egle and Adams, 1982).

Pretreatment with antiserum to met-enkephalin, which has negliable cross-reactivity with leuenkephalin, or any of the beta-endorphin fragments (Dr V. M. Wiegant, personal communication), did not inhibit the lowering of the blood pressure by alpha-methylnoradrenaline. In fact, the decrease in blood pressure had a tendancy to be prolonged when compared to control animals which had been pretreated with normal rabbit serum. It has been proposed that the enkephalins have a pressor role in the n. tractus solitarii (Petty and De Jong, 1982) and although the concentration of met- and leuenkephalin do vary, depending on the species and the particular area of the central nervous sytem, the concentration of met-enkephalin is greater in a ratio of 3:1 or even more (Yang, Hong and Costa, 1977; Kobayashi, Palkovits, Miller, Chang and Cuatrecasas, 1978; Hughes, Kosterlitz and Smith, 1977). Therefore, this prolonged depressor response, induced by alpha-methylnoradrenaline in the presence of met-enkephalin antiserum, may be explained on the basis that there is no met-enkephalin available to reverse the hypotensive action.

The local administration of antiserum to betaendorphin blocked the depressor response and reduced the bradycardia resulting from injection of alpha-methylnoradrenaline. It seems possible therefore that the catecholamine is releasing an endorphinlike peptide to induce the fall in arterial pressure. However, the decrease in blood pressure and heart rate seen after microinjection of beta-endorphin was slower than that caused by alphamethylnoradrenaline (Figs 1 and 2; Petty and De Jong, 1982). Perhaps a shorter fragment of betaendorphin is involved with which the antiserum cross-reacts. A possible candidate is alpha-endorphin [beta-endorphin-(1-16)], which also causes a doserelated fall in blood pressure and heart rate upon local application, with a shorter duration of action (De Jong et al., 1982).

In conclusion, it appears that a beta-endorphin-like peptide is involved in the hypotension resulting from central alpha-receptor stimulation in the normotensive animal. A site of this interaction is the $n$. tractus solitarii in the brain stem.

\section{REFERENCES}

Akil H., Hewlett W. A., Barchas J. D. and Li C. H. (1980) Binding of ${ }^{3} \mathrm{H}$-endorphin to rat brain membranes: Characterization of opiate properties and interaction with ACTH. Eur. J. Pharmac. 64: 1-8.

Bennett D. A., Defeo J. I., Elko E. E. and Lal H. (1982) Naloxone-induced reversal of clonidine but not hydralazine hypotension. Drug Devl Res. 2: 175-179.

Crawley J. N., Laverty R. and Roth R. H. (1979) Clonidine reversal of increased norepinephrine metabolite levels during morphine withdrawal. Eur. J. Pharmac. 57: $247-250$. 
De Jong W. (1974) Noradrenaline, central inhibitory control of blood pressure and heart rate. Eur. J. Pharmac. 29: 179-181.

De Jong W. and Petty M. (1982) Chemical stimulation of the nucleus of the solitary tract and the resulting blood pressure response. J. Cardiovasc. Pharmac. 4: S77-S80.

De Jong W., Petty M. A. and Sitsen J. M. A. (1982) endorphins and central cardiovascular regulation. $\mathrm{Br} . J$. Pharmac. 77: 333P.

Farsang C. and Kunos G. (1979) Naloxone reverses the anti-hypertensive effect of clonidine. Br. J. Pharmac. 67: 161-164.

Farsang C., Ramirez-Gonzalez M. D., Mucci L. and Kunos G. (1980) Possible role of an endogenous opiate in the cardiovascular effects of central alpha adrenergic stimulation in spontaneously hypertensive rats. J. Pharmac. exp. Ther. 214: 203-208.

Finley J. C. W., Lindström P. and Petrusz P. (1981) Immunocytochemical localization of $\beta$-endorphincontaining neurons in the rat brain. Neuroendocrinology 33: $28-42$.

Gold M. S., Redmond D. E. Jr and Kleber H. D. (1978) Clonidine blocks acute opiate withdrawal symptoms. Lancet II: 599-602.

Haeusler G. (1973) Activation of the central pathway of the baroreceptor reflex, a possible mechanism of the hypotensive action of clonidine. Naunyn-Schmiedebergs Arch. Pharmac. 278: 231-246.

Hughes J., Kosterlitz H. W. and Smith T. W. (1977) The distribution of methionine-enkephalin and leusineenkephalin in the brain and peripheral tissue. $B r . J$. Pharmac. 61: 639-647.

Kobayashi R. M., Palkovits M., Miller R. J., Chang K. J. and Cuatrecasas P. (1978) Distribution of enkephalin in the brain is unaltered by hypophysectomy. Life Sci. 22: $527-530$.

Kubo T. and Misu Y. (1981) Pharmacological characterization of the $\alpha$-adrenoceptors responsible for a decrease in blood pressure in the nucleus tractus solitarii of the rat. Naunyn-Schmiedebergs Arch. Pharmac. 317: 120-125.

Kunos G., Farsang C. and Ramirez-Gonzalez M. D. (1981) $\beta$-Endorphin: Possible involvement in the antihypertensive effect of central $\alpha$ receptor activation. Science 211: 82-84.

Law P. Y., Loh H. H. and Li C. H. (1979) Properties and localization of $\beta$-endorphin receptors in rat brain. Proc. natn. Acad. Sci. U.S.A. 76: 5455-5459.

McMurtry J. P., Wright G. L. and Wexler B. C. (1981) Spontaneous hypertension in cross-suckled rats. Science 211: $1173-1175$.

Nijkamp F. P. and De Jong W. (1975) $\alpha$-Methylnoradrenaline induced hypotension and bradycardia after administration into the area of the nucleus tractus solitarii. Eur. J. Pharmac. 32: 361-364.

Paalzow G. and Paalzow L. (1976) Clonidine antinociceptive activity: Effects of drugs influencing central monoaminergic and cholinergic mechanisms in the rat. Naunyn-Schmiedebergs Arch. Pharmac. 292: 119-126.

Palkovits M. and Jacobowitz D. M. (1974) Topographic atlas of catecholamine and acetylcholinesterase containing neurons in the rat brain. II. Hindbrain (mesencephalon and rhombencephalon). J. comp. Neurol. 157; 2942.

Palkovits M. and Záborsky L. (1977) Neuroanatomy of central cardiovascular control. Nucleus tractus solitarii: afferent and efferent neuronal connections in relation to the baroreceptor reflex arc. Prog. Brain Res. 47: 10-34.
Palkovits M., Mezey E. and Záborsky L. (1979) Neuroanatomical evidence for direct neural connections between the brainstem haroreceptor centres and the forebrain areas involved in the neural regulation of blood pressure. In: Nervous System and Hypertension (Meyer P. and Schmitt $H_{\text {, }}$ Eds), pp. 18-30. Flammarion. Paris.

Palkovits M. (1980) The anatomy of central cardiovascular neurons. In: Central Adrenaline Neurones (Fuxe K., Goldstein M., Hökfelt B. and Hökfelt T., Eds), pp. 3-17. Pergamon Press, Oxford.

Palkovits M. (1981) Neuropeptides and biogenic amines in central cardiovascular control mechanisms. In: Central Nervous System Mechanisms in Hypertension. Perspectives in Cardiovascular Research (Buckley J. P. and Ferrario C. M., Eds), Vol. 6, pp. 249-254. Raven Press, New York.

Pettibone D. J. and Mueller G. P. (1981a) $\alpha$-Adrenergic stimulation by clonidine increases plasma concentrations of immunoreactive $\beta$-endorphin in rats. Endocrinology 109: 798-802.

Pettibone D. J. and Mueller G. P. (1981b) Clonidine releases immunoreactive $\beta$-endorphin from rat pars distalis. Brain Res. 221: 409-414.

Petty M. A. and De Jong W. (1982) Cardiovascular effects of $\beta$-endorphin after microinjection into the nucleus tractus solitarii of the anaesthetized rat. Eur. J. Pharmac. 81: 449-457.

Petty M.A., De Jong W. and De Wied D. (1982) An inhibitory role of $\beta$-endorphin in central cardiovascular regulation. Life Sci. 30: 1835-1840.

Reid J. L., Dargie H. J., Davies D. S., Wing L. M. H., Hamilton C. A. and Dollery C. I. (1977) Clonidine withdrawal in hypertension; Changes in blood pressure and plasma and urinary noradrenaline. Lancet I: 1171-1174.

Rockhold R. W. and Caldwell R. W. (1980) Cardiovascular effects following clonidine microinjection into the nucleus tractus solitarii of the rat. Neuropharmacology 19: 919-922.

Schmitt H., Mme Schmitt H. and Fenard S. (1971) Evidence for an $\alpha$-sympathomimetic component in the effects of catapresan on vasomotor centres: Antagonism by piperoxane. Eur. J. Pharmac. 14: 98-100.

Smith W. L., Egle J. L. and Adams M. D. (1982) Adrenergic receptors in the nucleus tractus solitarii of the rat. Eur.J. Pharmac. 81: 11-19.

Talman W. T., Perrone M. H. and Reis D. J. (1980) Evidence for L-glutamate as the neurotransmitter of baroreceptor afferent nerve fibres. Science 209: 813-814.

Thoolen M. J. M. C., Timmermans P. B. M. W. M. and Van Zwieten P. A. (1981) Morphine suppresses the blood pressure responses to clonidine withdrawal in the spontaneously hypertensive rat. Eur. J. Pharmac. 71: 351-353.

Watson S. J., Akil H., Berger P. A. and Barchas J. D. (1979) Some observations on the opiate peptides and schizophrenia. Archs gen. Psychiat. 36: 35-41.

Yang H-Y., Hong J. S. and Costa E. (1977) Regional distribution of leu- and met-enkephalin in rat brain. Neuropharmacology 16: 303-307.

Zandberg P. and De Jong W. (1977) Localization of catecholaminergic receptor sites in the nucleus tractus solitarii involved in the regulation of arterial blood pressure. Prog. Brain Res. 47: 117122.

Zandberg P., De Jong W. and De Wied D. (1979) Effect of catecholamine-receptor stimulating agents on blood pressure after local application in the nucleus tractus solitarii of the medulla oblongata. Eur. J. Pharmac. 55: 43-56. 